\title{
Pilot projects empower district supply chain management staff to strengthen health services in Indonesia
}

\author{
Setiawan Suparan ${ }^{1 *}$, Ketut Adnyana ${ }^{2}$, Ivan Surya Pradipta ${ }^{3}$, Nani Sukasediati ${ }^{4}$, Prihatiwi Setiati ${ }^{5}$ \\ From The 2nd People that Deliver (2nd PtD) Global Conference on Human Resources in Supply Chain \\ Management \\ Copenhagen, Denmark. 29-30 October 2014
}

\section{Background}

Indonesia comprises 17,000 islands and 495 districts. Decentralization mandates district health services, but ensuring proper supply chain management (SCM) capacity at the district level is a challenge. The ministry of health developed and implemented SCM training modules and guidelines; however, weaknesses in the system remain, particularly related to human resources. The ministry in collaboration with universities and funders, piloted two projects that empower SCM staff. It will use the results to strengthen SCM at the district level.

\section{Method}

Two pilot projects, with different timeframes and funding, focused on staff empowerment, local ownership, team work, local problem solving, and enhanced professionalism. The pilots were built around a standard SCM cycle and used self-assessments to identify gaps in the SCM system. The approach also facilitated team work to develop and implement a corrective action plan.

\section{Results}

The pilot sites exhibited the same gaps. Which included: limited human resource capacity, and a lack of appropriate standard operating procedures (SOPs). A three-month internship for newly graduated pharmacists and pharmacy students, with SCM skills, was used to strengthen HR capacity. SCM training conducted by the interns for district SCM personnel proved effective, improving staff performance. Other interventions included reviewing and revising both SOPs and a quality assurance check list for
SCM. Collaboration among SCM staff and managers was intensified, using an Integrated Drug Management approach. All the pilot sites now use standard SCM SOPs and have an Integrated Drug Management team.

\section{Discussion}

The internship program was very effective in increasing SCM performance and pharmacy services at the district level. We confirmed that SOPs are critical tools that should be used to facilitate standard, good quality performance. Empowering district personnel to review their own SCM program in a systematic manner and to prepare a follow-on action plan proved highly successful; this approach will now be used in expanded efforts to improve the district level SCM system and staff capacity.

\section{Lessons learned}

Empowering SCM staff through local ownership and selfassessment is an effective and sustainable way to create SCM interventions tailored to district needs. It also builds district staff commitment and confidence. Newly graduated pharmacists with SCM skills can act as change agents for improving SCM.

\section{Authors' details \\ ${ }^{1}$ USAID | DELIVER PROJECT, Jarkata, Indonesia. ${ }^{2}$ School of Pharrmacy, ITB/ \\ Bandung Institute of Technology, Jawa Barat, Indonesia. ${ }^{3}$ Faculty of Pharmacy University of Padjadjaran Bandung Unpad, Jawa Barat, Indonesia. \\ ${ }^{4} \mathrm{WHO}$, Jakarta, Indonesia. ${ }^{5}$ Ministry of Health, Jakarta, Indonesia.}

Published: 17 December 2014

\footnotetext{
* Correspondence: iwan@yahoo.com

'USAID | DELIVER PROJECT, Jarkata, Indonesia

Full list of author information is available at the end of the article
} 
doi:10.1186/2052-3211-7-S1-P15

Cite this article as: Suparan et al:: Pilot projects empower district supply

chain management staff to strengthen health services in Indonesia.

Journal of Pharmaceutical Policy and Practice 2014 7(Suppl 1):P15.

Submit your next manuscript to BioMed Central and take full advantage of:

- Convenient online submission

- Thorough peer review

- No space constraints or color figure charges

- Immediate publication on acceptance

- Inclusion in PubMed, CAS, Scopus and Google Scholar

- Research which is freely available for redistribution

Submit your manuscript at 